\title{
Fracking fracas
}

\section{Although a policy consensus regarding shale gas is emerging in the United States, arguments about fracking continue unabated in Europe.}

Natural gas from organic-rich shale deposits is widely touted as a bridge to a cleaner future. According to supporters, shale-gas use will deliver energy security and reduce energy costs. They also claim that burning shale gas rather than coal for energy will reduce greenhouse gas emissions from power plants. Opponents, on the other hand, see shale gas as a bridge to nowhere. These detractors point to methane emissions and other environmental and safety concerns associated with shale-gas extraction through hydraulic fracturing, or 'fracking. They also fear that in the long term, shale gas will be fully exploited in addition to, rather than instead of, oil and coal.

Many peopled concerned about the environment nevertheless see a place for shale gas as a cleaner alternative to oil and coal. Others would prefer shale gas to be left in the ground, arguing that policymakers should focus instead on energy efficiency and renewables. For nations such as the United States, that simply is not going to happen. The powers that be seem convinced that shale-gas exploitation will have significant economic benefits.

Setting aside economics, how will shale gas contribute to climate change mitigation? Certainly, natural gas - whether from shale or conventional sources - is the cleanestburning fossil fuel. However, some critics contend that that methane leakage from shale-gas extraction will cancel out any climate benefits. But that is a minority view. In the minds of most policymakers and politicians in the US that the use of plentiful, cheap natural gas for electricity generation is good for climate change mitigation is beyond dispute. Only when new climate mitigation technologies such as carbon capture and storage are implemented on a large scale assuming that they ever will be - is that situation likely to change. So for both economic and environmental reasons, many people see shale gas as an important part of the energy mix.

In an article entitled 'Is shale gas good for climate change' (Daedalus 141, 72-80; 2012), Harvard academic Daniel Schrag argues that the real benefit of shale gas to a responsible climate policy is essentially political: “... the main impact of shale gas on climate change is neither the reduced emissions from fuel substitution nor the greenhouse gas footprint of natural gas itself, but rather the competition between abundant, low-cost gas and low-carbon technologies, including renewables and carbon capture and storage." Schrag even suggests that the conventional use of coal in the US could be eliminated if the gas industry and environmental groups got together to counter the coal lobby.

Meanwhile, shale-gas production is already booming in North America. In the US, shale gas enjoys broad bipartisan support in both the Senate and the House of Representatives. President Barack Obama and Senate Energy and Natural Resources Committee Chairman Ron Wyden (the Democrat Senator for Oregon) back 'responsible exploitation of shale-gas resources. Nevertheless, they favour more federal oversight and regulation than the industry would like. This is particularly the case in relation to public safety and environmental protection. Indeed, as mentioned by Anna Petherick in her News Feature (page 436) on where US climate policy may now be headed, emissions standards for fracking have already been introduced using the Clean Air Act.

The situation in Europe is rather different, negotiations so far being characterized by fractiousness rather than consensus. As reported by Sonja van Rennsen (page 440), the European Union has been tardy in developing a coherent shale-gas policy. Bust-ups in Brussels between shale-gas advocates and critics have not helped. In addition, individual EU member states differ radically in the extent that they are likely to benefit from shale-gas extraction. As van Rennsen explains, Poland stands to benefit greatly from a shift from coal to shale gas, and is pushing ahead with its own nation shale-gas policy, taking an active lead at EU level. Other member states will benefit less and are in no hurry to exploit shale-gas resources. In some European nations, such as the United Kingdom, there is vociferous opposition to shale-gas extraction, especially from green campaigners and people living in regions already affected by exploratory test-drilling, or where decisions on planning applications to drill for shale gas are pending (see, for example, http://frack-off.org.uk/locations).

Is confidence in the US about the claimed economic and climaterelated benefits of shale gas justified?
Geophysicist David Hughes of the Post Carbon Institute, Santa Rosa, California, thinks not. He recently prepared a report (http://www.postcarbon.org/drill-baby-drill) that paints a less than rosy picture for the future of the shale-gas and oil industry. If his concerns are warranted, Europe might be well advised to err on the side of caution but it should avoid becoming paralysed by indecision.

Hughes assessed the production history and the economic, environmental and geological constraints of shale-gas and shale-oil resources in North America, using data from 65,000 wells. He found that wells deplete quickly and that the long-term potential of shale resources is limited by the 'exploration treadmill', implying that it will be difficult to maintain production. Moreover, although non-conventional fossil-fuel resources such as shale gas and oil exist in vast deposits, Hughes finds that the rapid scaling-up of production to 'markettransforming levels' will be an almighty task given the capital expenditure required and the logistics involved. As he put it in the report, "the big 'tanks' of these resources are inherently constrained by small 'taps."

As reported recently in Nature (http://go.nature.com/yVzhXP), China is having problems developing its own shalegas reserves, due to the relatively complex nature of its shale deposits, and aboveground challenges resulting from lack of infrastructure and experience.

Writing in the same issue of Nature (http://go.nature.com/xecmer), Hughes concludes from his study of the

North American shale-gas industry that the 'heady' claims made for the 'shale revolution' do not stand up to scrutiny: "production of shale gas and oil in the United States is overhyped and the costs are underestimated,' he says.

Hughes considers it likely that shalegas and oil production will continue for a long time, albeit at a level significantly below industry and government forecasts. In his view, there is an urgent need for a 'more realistic' debate around shale gas and oil that accounts for "the fundamentals of production in terms of sustainability, cost and environmental impact". We, and no doubt our readers, will be following developments with interest. 